\title{
Lord Denning: An Antipodean Appreciation
}

\author{
The Hon. Fustice M. D. Kirby, C.M.G. *
}

\section{End of an Era}

Lord Denning was fond of saying that he had every Christian virtue save resignation. In 1982 he was one of the few remaining judges in England not subject to compulsory retirement. To use his own words he was "one of the few judges who have freehold." However, in a statement made by his clerk in July 1982 , he said that he had intended for some time to retire at the end of the legal year "because of his advanced age." 1 He was then, as they would have said at the time of his birth, in the 83rd year of his age.

The initiating circumstances for his retirement was an unhappy controversy over his book What Next in the Law? The book, the third since his 80th birthday, included a few typically blunt observations concerning the jury service of citizens of West Indian or other non-English ethnic origin. When these comments became public, calls for his resignation were made by the Society of Black Lawyers in England and by others. Even before the announcement of Lord Denning's retirement was made, Mr Rudy Narayan, Secretary of the Society wrote to the Times:

"Lord Denning remains one of the greatest judicial minds of this century; he was my sponsor on call to the Bar but that should not be taken too heavily to his discredit ... A great judge has erred greatly in the intellectual loneliness of advanced years; while his remarks should be rejected and rebutted he is yet, in a personal way, entitled to draw on that reservoir of community regard which he has in many quarters and to seek understanding, if not forgiveness." 2

Lord Denning was no stranger to controversy. Yet the controversy which surrounded his book and his remarks was bitter and personal. Almost certainly it hastened his decision to 'bring forward' the announcement of his retirement. ${ }^{3}$ In correspondence, writing of the controversial book, he expressed the feeling that it

*President of the Court of Appeal, Supreme Court, Sydney. Formerly Chairman, Australian Law Reform Commission and Judge of the Federal Court of Australia.

1. Peter Post quoted Law Talk 153(NZ Law Society), 14 July 1982, 7.

2. R. Narayan, Times quoted ibid.

3. P. Post, ibid. 
was "about the right time" for him to retire "whilst I am still in good form and able to do my work." "Lord Denning urged upon me the merit of much of what was in it when it was reissued soon afterwards. He said it was worth reading "because it deals a great deal with law reform." ${ }^{5}$ So it does. So does much of his writing in and out of court.

The retirement of such a towering figure of the common law certainly marked the end of a legal era. It removed from one of the highest judicial offices in the English speaking world, a judge who had been dedicated to law reform, and not content to leave reform solely to Parliament, whether or not helped by law reform agencies or other bodies.

Who is Lord Denning? Why has he been such a controversial judicial figure? Will his achievements last? What lessons does his career hold for the judiciary and the administration of justice in far-away countries of the common law, such as Australia?

\section{Lord Denning the Man}

Alfred Thompson Denning was born in 1899, the son of a draper in the village of Whitchurch, where he still lives. He was one of five brothers. One became a General, another rose to be an Admiral. Lord Denning began life as a teacher but later returned to Oxford and a pursuit of the law.

Two of his brothers were killed in the First World War. One, Jack, the eldest son, died leading his men at Flanders. The other, Gordon, a sailor, was killed in the Battle of Jutland, aged 19. In his book The Due Process of Law, Lord Denning finishes with a personal epilogue, written in a special style of English prose of which he is a modern master:

"I remember the telegram coming. Mother opened it with trembling fingers.

'Deeply regret ... died of wounds'. She fainted to the floor. A few days later came a letter which was found in his valise after his death. Mother and father - poor dears - they were to lose another son before that war was over ... Reg is now a General - retired. Norman is now an Admiral - retired. But Jack and Gordon - they were the best of us ... The poppies slipped from my hand to the floor. Eyes filled with tears. It was the eve of Remembrance Day." 6

Lord Denning himself fought at Picardy in the First World War. "Only there for the last nine months. Too young to go before. I came through unhurt." ${ }^{7} \mathrm{He}$ won scholarships and First Class Degrees in Mathematics and Jurisprudence. In 1923 he was called to the Bar. He soon learned that the law and justice were not always the same thing. Cases came to him for opinion. In accordance with the binding authority of the highest courts, they required conclusions that struck him

4. Letter of Lord Denning to the author, 14 July 1982.

5. lbid.

6. Lord Denning, The Due Process of Lam (1980), at pp. 250-251.

7. Ibid., at p. 249. 
as unjust. "The House of Lords had decided it. That was the end of the matter", he later wrote. Cases of apparent injustice disturbed Denning. He was later to describe binding principles as "false idols which disfigured the temple of the law." In the fullness of his career, he was to come to a position where he could do something about them.

In 1944 he was appointed a judge. Accordingly, he served in judicial office for 38 years. He was elevated to the English Court of Appeal in 1948 and to the House of Lords in 1957. In 1962 a vacancy occurred in the position of Master of the Rolls. Lord Denning took this position. There he remained until July 1982 . At the age of 83 , he admitted no diminution in intellectual vigour. If anything, in his later years, he seemed to show an increasing reformist zeal. His appeals to the 'broad rule of justice itself' became more frequent and more insistent in the closing years of his judicial service.

For a judge to take this course under our system of law is unusual. For the presiding judge of England's second highest court to do so, and frequently to carry his colleagues with him, is nothing short of remarkable. He has had his critics. They are not confined to the clubs where gather the judges and lawyers, or the boardrooms of newspapers' offices in Whitehall or other places where disappointed or disaffected litigants collect. But observers of the common law world could not ignore the extraordinary impact of his intellect.

\section{Stability in Reform}

Lord Denning illustrates the difficulty facing all law reformers, whether judicial or otherwise. The law is a force for stability and predictability in society. People need to know what the law is so that they can live peacefully together without resort to violence or expensive litigation. But times change. The inventions of science and technology present challenges to the law which often speaks in the language of a previous time. Moral and social attitudes change rendering previously accepted values suspect or unpalatable. Well established principles which may have endured for centuries can lead to results that strike the modern judge as unjust but the law, nonetheless.

The original genius of the common law of England lay in its capacity to adapt its rules to meet different social conditions. The advent of the representative Parliament has tended to make judges, including appeal judges, reticent about inventing new principles of law or overturning decisions that have stood the test of time. "Heresy is not the more attractive because it is dignified by the name of reform," 8 declared Viscount Simonds, one of Lord Denning's critics. "It is even possible that we are not wiser than our ancestors. It is for the legislature, which does not rest under that disability, to determine whether there should be a change in that law and what the change should be." 9 
Denning suffered no tongue-tied inhibitions just because Parliament could change the law. Parliaments have generally shown little interest in the reform of wide areas of the law. Individual, small injustices may not amount to many votes or much public interest. Repeatedly in his thirty-eight years as a judge, Denning expressed impatience with the notion that the judge's duty was blindly to follow precedents or, if there were none, to do nothing, leaving it to the legislators to act.

In October 1979 addressing the National Conference of the English Law Society he again took his stand for the judicial role in law making:

"Law reform ... should not be left solely to the Law Commissions. There is a great movement today which says that judges should not do anything to reform the law, that they should treat their old cases as binding upon themselves and do nothing. I give you an example ... [In a recent case] I said there should be a radical reappraisal of our system of assessing damages for personal injuries and, in the House of Lords, Lord Scarman giving the one judgment said:

'Yes I agree with Lord Denning there ought to be a radical way of reappraisal.'

But he went on to say that we will not do it. We will leave it to other bodies. The Law Commissions can do all this and eventually report. How long will it take? Will it ever take place? I would suggest that there is still a field for judge made law in our land. Of course, I do not get my own way as a rule." 10

Certainly, an aspect of the original common law system was constant law reform: judges and lawmakers working together to mould principles to fit the new circumstances of the case before them. But such inventiveness is not now common, whether in England, Australia, or other common law countries. Lord Denning again:

"Writing in the Times of 5 January 1977, Sir Leslie Scarman said: 'the past 25 years will not be forgotten in our legal history. They are the age of legal aid, law reform and Lord Denning'. I am gratified by the tribute but I feel that many of my endeavours have failed - at any rate so far. The strict constructionists still hold their fortress. The officious bystander still dominates the field. The Court of Appeal is still bound hand and foot. The powerful still abuse their powers without restraint." 11

This is not to say that Denning did not try. Certainly, he was never prepared to leave it to law reform commissions and bureaucrats to improve laws which, in his view, judges could perfectly well attend to. In one case, for example, he found that courts should imply into a tenancy agreement, which said nothing about the

11. Lord Denning, The Discipline of Lam (1979), at p. 315. 
subject, an obligation upon the landlord to take care that lifts and staircases were reasonably fit for the use of tenants and their visitors.

"I am confirmed in this view by the fact that the Law Commission in their codification of the law of landlord and tenant, recommend that some such terms should be implied by statute ... But I do not think we need to wait for a statute. We are well able to imply it now in the same way as judges have implied terms for centuries. Some people seem to think that now there is a Law Commission the judges should leave it to them to put right any defect and to make any new development. The judges must no longer play a constructive role. They must be automatons applying the existing rules. Just think what this means. The law must stand still until the Law Commission has reported and Parliament passed a statute on it: and, meanwhile, every litigant must have his case decided by the dead hand of the past. I decline to reduce the judges to such a sterile role so I hold there that there is clearly to be implied some such term as the Law Commission recommends." 12

This passage gives the flavour and texture of this extraordinary judge's written style. Short sentences. Pungent phrases. Headings in his judgments to guide the reader through his reasoning. Even his critics and enemies acknowledge his skill in handling the legal techniques and in presenting them in prose which is startling because of its contrast to the normal style in which judgments are written. That is not to say that everybody approves of his very special way of writing English. A confessedly 'carping' review of his 1979 book The Discipline of the Lam was rather severe:

"The style is unmistakable. And unmemorable. Judicial staccato. Not a cadence in sight. I wonder if that is the unfortunate consequence of writing all those longhand notes in the early days on the Bench while those below waited for the pen to be laid down, for the 'ye-es', for the raised eyes."13

To show that these matters are simply matters of taste, another reviewer of the same book asserts "the book is intensely readable." ${ }^{4}$ There is little doubt that elegant or not, it is a prose style which is powerful for its simplicity and directness. It is the prose style of an evangelist and propagandist: appellations which Lord Denning would not shun.

\section{Denning the Reformer}

Needless to say Lord Denning's view of his role frequently drove him into dissent from other more conventional judges. Even where, in the Court of Appeal, he carried the day, he was sometimes reversed in the House of Lords in chilling

12. Liverpool City Council v. Irwin [1976] Q.B. 319, 332.

13. J. A. G. Griffith, Book Review (The Discipline of the Lam), in (1979) 42 M.L.R. 348.

14. C. H. Gage, Book Review, in (1980) 39 C.L.7. 194, at p. 195. See also review by T. Harper, in (1979) 129 New L.7. 83. 
language. One of his abiding concerns was to reform the law of contract. He waged a battle over a quarter of a century against the unfair exclusion of claims by written terms, sometimes found obscurely on the back of a ticket or form. But to his 1951 plea for the law to look at the reality of contract relationships, the Lords answered coldly. "Phrases occur", said Viscount Simon "which give us some concern." 15 Lord Simonds added, "It is no doubt essential to the life of the common law that its principles should be adapted to meet fresh circumstances and needs. But I respectfully demur to saying that there has been or need be any change in the well-known principles of construction of contracts." 16

Undeterred, Denning went on to effect important changes in contract law, guided by justice and commercial morality, as he saw it. His reformist enthusiasm was not limited to contract cases. He helped to dispose of the principle that a hospital was not liable for the negligence of its professional staff. He decided the first of many cases in which a deserted wife was held entitled to remain in the matrimonial home. In 1951 he wrote a famous dissenting judgment lamenting the calamitous exception from the law of negligence which relieved many, including professional advisors, from actions for damages for loss caused by negligent as distinct from fraudulent misrepresentations. He did not hesitate to dissent, although he was then but recently added to the Court of Appeal. The language he used was typical:

"This argument about the novelty of the action does not appeal to me in the least. It has been put forward in all the great cases which have been milestones of progress in our law. In each of these cases the judges were divided in opinion. On the one side there were timorous souls who were fearful of allowing a new cause of action. On the other side there were the bold spirits who were ready to allow it if justice so required. It was fortunate for the common law that the progressive view prevailed." 17

Although in 1951 the progressive view did not prevail, in 1963 the House of Lords introduced a limited duty of care for persons who take upon themselves to supply information or advice to people whom they know will place reliance on it. ${ }^{18}$ Lord Denning's dissent of 1951 became the rule in 1963. It has now been substantially adopted in other jurisdictions, including Australia. ${ }^{19}$

\section{Be You Never So High}

A Judge who so often turned the law upside-down was bound to attract criticism. In 1971 some thought he went too far when he held that decisions of the House of

15. British Movietone Ners Lid. v. London and District Cinemas Lid. [1952] A.C. 166, 181-182.

16. Ibid., at p. 188.

17. Candler v. Crane, Christmas E Co. [1951] 2 K.B. 164, 178.

18. Hedley Byme ES Co. Lid. v. Heller ES Parneen Ltd. [1964] A.C. 465.

19. Mutual Life and Citizens' Assurance Cr. Ltd. v. Evatt [1971] A.C. 793. See now Shaddock and Associates Pty. Ltd. v. Parramatta City Council (1981) 55 A.L.J.R. 713. 
Lords not only did not bind the Lords themselves but might not bind the Court of Appeal. He could not abide a decision of the Lords which had abolished punitive damages. He saw it as having "knocked down the common law as it had existed for centuries." ${ }^{20}$ Carrying two colleagues with him, he held that this rule of the Lords "should not be followed ... because the common law of England on this subject was so well settled before $1964 \ldots$ that it was not open to the House of Lords to overthrow it." 21

It remained for Lord Chancellor Hailsham to deliver a sharp rebuke. "It is necessary", said the Lord Chancellor, "for each lower tier, including the Court of Appeal, to accept loyally the decisions of the higher tiers." 22 But it was not only Denning's judicial and more conservative legal critics who expressed astonishment at his views. Some believed that Denning was excessively teleological in his approach. He was charged with thinking of the result he wanted before he considered the legal reasoning on which it had to be founded. This process was all very well if there was agreement on the first principles which werc guiding him. But should a judge, near to the apex of the legal system, be able to give vent to his personal value system, thereby disrupting settled principles and creating confusion and uncertainty in the law?

During the 1970s Denning took a leading part in the assault on Ministerial and Executive authority. He leapt to the defence of the little man in combat with the bureaucracy. He appealed to the old Bill of Rights. ${ }^{23}$ In January 1977, he took part in the decision by which the Court of Appeal granted an injunction on the application of a private citizen directed at a union which, contrary to law, had announced a ban on postal services to South Africa. ${ }^{24} \mathrm{He}$ rejected the claim that the Attorney-General's fiat was necessary to permit a private citizen to bring the case.

"Every individual in the land has an interest in the channels of communication being kept open. The law shall be obeyed. Even by the powerful. Even by the Trade Unions. We sit here to carry out the law. To see that the law is obeyed. And that we will do. A subject cannot disregard the law with impunity. To every subject in this land, no matter how powerful, I would use Thomas Fuller's words over three hundred years ago 'Be you never so high, the law is above you'." 25

Subsequently the House of Lords reversed this decision holding, in effect, that the courts could not question the long established rule that it was for the

21. Ibid., at pp. $380-381$.

22. Broome v. Cassell $[1972]$ A.C. $1027,1054$.

23. Gouriel v. Union of Post Office Workers [1977] 2 W.L.R. 310, 331 (on appeal to the House of Lords, appeal allowed) [1978] A.C. 435.

24. Gouriet v. Union of Post Office Worken [1977] 2 W.L.R. 310.

25. Ibid., at p. 331 . 
Attorney-General not the courts to decide whether such actions should be brought. This very question is now under study in the Australian Law Reform Commission. There are some who say that Lord Denning's view, though held not to be good law, may yet be right in principle and become the law. Others assert that he is too concerned with the 'little man' and forgets that, in the modern state, the elected government represents the mass of 'little people' and is no longer the Crown exerting selfish, overweaning power.

Other critics point to Denning's concern to uphold valiantly Christian principles of morality and to impose them on all members of a pluralistic society. In one famous case, he denied relief to a young girl, Gillian Ward, who had been expelled from a Teachers' College after being found with a man in her room at night.

"I do not think she has been treated unfairly or unjustly. She had broken the rules most flagrantly. I say nothing about her morals. She claims that they are her own affair. So be it ... But instead of going into lodgings, she had this man with her, night after night. That is a fine example to set to others! And she is a girl training to be a teacher! She would never make a teacher. No parent would knowingly entrust their child to her care." 26

The same strong language came out in his well known report on the 'Profumo Affair' in 1963. He did not hesitate to lay responsibility squarely on the Prime Minister and his colleagues. The report rings with his moral outrage. Its impact was the more electrifying because of this.

Those who did not complain about his 'blind spot' where matters of morality were involved, asserted that he was just a conservative member of the English ruling class who reflected the attitudes of a Britain in which he grew up and which was then still a great Imperial power. Wherever an international element is involved in the case, it is said, Lord Denning usually came down in favour of English law and English courts to the exclusion of applying foreign law to the parties' transactions, although towards the end of his judicial career he has faced realistically the 'incoming tide' of the law of Europe as it affected the United Kingdom.

What most exasperates Lord Denning's critics is what is seen to be an idiosyncratic claim to plain talking morality:

"He uses history as if it were a box of goodies from which it is possible to extract all sorts of useful arguments. Whether they meant then what they can be interpreted as meaning now worries him not at all. He must know that the 19th Century was not like that. But if it were, so much the better for his analysis of what characterises the 20th. So let's pretend. For all his private searching in his books Lord Denning is the most unhistorical of reformers ... My view of where the line should be drawn between judicial power and 
Ministerial power will not necessarily be that of the next man. But it is likely that he and I will agree that the line is political. I wish Lord Denning would. He plays not only the Ace of Trumps but all his 52 cards as if God had dealt them to him. There are other players who also have a view of justice, different though that view may be from Lord Denning's . .."27

According to this critic, Lord Denning's value as an innovator could not be denied. Certainly, when his sympathy was aroused, he could be a most formidable champion.

"But his view of justice is too personal, too idiosyncratic, too lacking in principle for greatness. He may instruct us, as he claims to do, in the principles of the law. But the grasp of political principle, the insight into the nature of the change that society is currently undergoing, for these he shows no special flair, no particular understanding." 28

The controversies that surrounded Denning, the law reformer in the courts, persisted into his 82 nd year. Not only did his views on the scope of the privilege of journalists give rise to comment. ${ }^{29}$ His observations in the jury vetting case ${ }^{30}$ also drew a dissenting voice from the Times editorialist. This was a case where Lord Denning sought to strike a blow for a cause he has long championed: a new approach to statutory interpretation. The editorialist cried caution:

"What Lord Denning is trying to do is to import into the interpretation of statutory provisions the same degree of judicial creativity as is normally applied to developing the common law. The tradition of English law does not support that approach. It may be acceptable to introduce a qualifying element of equity into the harsh rules of statutory construction. [But] this would be, under his formula, for the majority of judges to determine a sensible result. That would be to usurp Parliament's function and give judges a power which the vast majority of them neither seek nor are capable of exercising." 31

Once again, Lord Denning may simply have been ahead of his time. In Australia, at least, important changes have been introduced in the rules governing statutory construction. ${ }^{32}$ Denning's acceptance of reform undoubtedly stimulated the greater willingness to accept the reality of judicial creativity and to provide new rules designed to acknowledge and direct that creativity. In May 1980 the Times editorialist returned to this theme in comments on Lord Denning's ruling about journalists' privilege:

27. Griffith, supra n. 13, at p. 349.

28. Ibid., at p. 350 .

29. Lord Denning, The Due Process of Law (1980), at p. 30; What Next In The Law (1982), at p. 328.

30. $R$. v. Sheffield Crown Court, ex p. Bromnlow, unreported, Times L.R. for 3 March 1980.

31. The Times (London), 3 March 1980.

32. See, e.g., the Acts Interpretation Amendment Act 1984 (Cth), assented to on 25 May 1984, and the Interpretation of Legislation Act 1984 (Vic), assented to on 23 May 1984. 
"Lord Denning, this time, is on the wrong side ... What Lord Denning has done is to lay down a new test, based on whether a court thinks the journalist or his employer has acted properly and responsibly: 'If a newspaper should act irresponsibly, then it forfeits its claim to protect its sources of information.' That is neither a logical nor a necessary criterion. It would mean that a potential source, even one who revealed a relatively innocuous piece of information, would be at risk of having his identity divulged because his contact was adjudged to have acted irresponsibly. The courts are far from being the best judges of what is responsible journalism. Their task should be to determine the balance of public interest, not to judge journalistic ethics. The Court of Appeal has done a disservice to the cause of press freedom." 33

To the day of his retirement, Lord Denning was followed by adulation and calumny, praise and blame and always controversy. Why should this be so? Because he is one of the chief proponents of the reformist role of the English judge. He enjoyed the approbation of those who agreed with his decisions. He had to endure the attack of those who did not. Each he accepted with equal fortitude.

\section{Denning and Parliament}

There are some judges of our tradition who, for fear of being accused of "judicial imperialism", ${ }^{34}$ would not even venture to criticise a statutory provision which they felt, in a case coming before them, worked an injustice. An English Attorney-General once told the House of Commons that "it is a most important principle of our constitutional practice that judges do not comment on the policy of Parliament, but administer the law, good or bad as they find it. It is a point of doctrine on which the independence of the judiciary rests." 35

In 1950, Lord Denning cautioned against taking this view too far. He pointed out that the judges had often called attention to laws being in need of reform. He quoted Lord Justice Scrutton who, after wrestling with a very troublesome provision under the Rent Acts said that he was sorry that he could not order "the costs to be paid by the draftsman of the Rent Restrictions Acts and the members of the Legislature who passed them and are responsible for the obscurity of the Acts." ${ }^{36}$ Obviously, Denning shared this view:

"I do not myself see why responsible comments or suggestions on the way in which Acts work, intended only in the public interest, should be regarded as an infringement of the sovereignty of Parliament. This applies not only in respect of law laid down by Judges or enactments of Parliament in ancient times, but also in respect of enactments in modern times, subject to the

33. The Times (London), 8 May 1980.

34. See G. S. Reid, "The Changing Political Framework", Quadran Jan-Feb 1980, 5, at pp. 12-13. 35. Cited by Lord Denning in his Holdsworth Lecture, "The Independence of the Judges" in B. W. Harvey (Ed.), The Lanyer and 7ustice (1978) 53, at p. 63.

36. Ibid., at p. 66 . 
qualification that the Judges must never comment in disparaging terms on the policy of Parliament, for that would be to cast reflection upon the wisdom of Parliament and that would be inconsistent with the confidence and respect which should subsist between Parliament and the Judges. Just as members of Parliament must not cast reflections on the conduct of Judges, so Judges must not cast reflections on the conduct of Parliament. If everyone observes these rules, there will be no conflict." 37

The Australian Law Reform Commission now collects and reports to Parliament, judicial and other suggestions for law reform. ${ }^{38}$ I am sure Lord Denning would approve this innovation; though never did he regard proposals to Parliament as foreclosing his opportunities for judicial reform, without troubling Parliament.

\section{Lion or Tribune?}

For every reformer on the bench like Lord Denning there are many more who have their doubts. Some, such as Sir Garfield Barwick, past Chief Justice of Australia, deny that even the highest court may legitimately 'change' the law. ${ }^{39}$ Others, whilst acknowledging that judges may be good "contributors and formulators" ${ }^{40}$ do not believe that they are the stuff of which reform is made. ${ }^{41}$ On this view enthusiasm is not and cannot be a judicial virtue. ${ }^{42}$ Even if not mere ciphers, mechanically discovering, declaring and applying the law, they see the judicial role as very severely circumscribed by its lack of democratic legitimacy. Judges are not elected. ${ }^{43}$ Parliaments, in our generation at least, are. On this view, whatever may have been permissible to the Judges of ancient times, it is impermissible today. Moreover, it flies in the face of the community's simplistic notion of democracy. If too candidly disclosed, it may undermine the appearance of judicial impartiality and neutrality. ${ }^{44}$

Judges are urged by people who hold this view, not to confuse their role with the frank law making function of a legislature. ${ }^{45}$ They do not have its warrant from the people. They are generally members of the older generation. They are not reflective of the whole variety of the population. ${ }^{46}$ If the law is not satisfactory, the

37. Ibid., at p. 67.

38. Australian Law Reform Commission Anmal Report 1983, p. 7; "Community Reforms" |1984| 34 Reform, pp. 50-54.

39. G. E. Barwick, "Judiciary Law: Some Observations Thereon", (1980) 33 C.L.P. 247.

40. P. Devlin, The fudge (OUP, 1979), at p. 12.

41. J. A. Griffith, The Politios of the fudiciany (Fontana, 1977), at p. 208.

42. Devlin, supra n. 40 , at p. 5.

43. Devlin, ibid, at p. 10; B. Abel-Smith and R. Stevens, Lawyers and the Courts (Weinemann, 1967), at p. 121 .

44. Lord Reid, quoted in Griffith, supra n. 41, at p. 179.

45. Lord Jowitt, in Abel-Smith and Stevens, supra n. 43, at p. 287.

46. Devlin, supra n. 40 , at p. 53. 
people can blame Parliament. If the shoe pinches, the brake on reform is a brake applied by Parliament not by the Judges. ${ }^{47}$ Where Parliament fears to tread, the courts should be specially careful. ${ }^{48}$

The establishment of permanent law reform commissions, to help Parliament with the reform of the law, provides the Judges who hold to these views with further ammunition against their reformist brethren. Law reform bodies have developed techniques of widespread community consultation which are not available to Judges. At best, Judges merely have only the parties before them. They might not be representative of the whole community. Almost surely they would not provide the Judge with the economic, scientific and other expertise available to professional law reformers. The first Chairman of the English Law Commission, Lord Scarman, referred to these matters in distinguishing his approach to law reform, as a Judge, from Lord Denning's:

"I disagree with Lord Denning. I believe in law reform by statute, and preferably by statutes introduced after full consideration of the problem by the Law Commission, or other body charged with considering law reform, or the implications of law reform. Lord Denning thinks that one can take a short cut by judicial decision, avoiding all the parliamentary delays, and indeed the delays associated with a thorough-going and patient examination of the problem by a body like the Law Commission. I profoundly disagree with Lord Denning on this. And I think if I had any criticism of Lord Denning as a developer of the law, it is that he develops it at a cost of uncertainty. The question is where the line is to be drawn. I go along with Lord Denning to this extent, that I think there is room for a certain degree of development of the law by judicial decision. But I do think that the development has to be in the minor key. One cannot change a Rule of Law which is clear and well established merely because it produces a hard case, that is to say, works injustice." +9

In response, Denning had put the judicial reformers' point of view. Judges have been developing the law for centuries. Parliament has neither the time nor the inclination to attend to all the necessities of law reform. ${ }^{50}$ If it does attend to some of them, the delay is crippling. ${ }^{51}$ It will not help the litigants in the particular case before the Judge:

"Well, I am afraid the present trend is that the Judges should not do anything new. They should not alter the law. There should be no law making by the judges. Everything should be left to Parliament or to the Law Commission. I

47. Lord Parker, Hansard, 5th Session (HL), Vol. CCLVIII, 9 June 1964, Col. 1071-2.

48. Lord Reid, in Griffith, supra n. 41, at p. 183.

49. Lord Scarman, interviewed by Hugo Young, Talking Law, BBC, 16 Sept. 1979.

50. Lord Denning, in Paterson, The Lam Lords (Macmillan, 1982), at p. 181.

51. Lord Reid, in Paterson, ibid., at p. 182. 
take a completely different view. I think the judges alone can deal with the instant case, to remedy the wrong in the case which is before them. If you wait for legislation you may wait for years and years and they can't affect the instant case - only the future cases. So I hope the judges, if they are strong enough, will continue to develop our law as by history they've done in the past ... If you have judges of the best kind, who are ready to take a broad view, you can get it done as well or better by judges than from all these long inquiries by Law Commissioners and the like. But of course, it depends on the judges." 52

Standing halfway between Denning and Scarman, Lord Justice Kerr, also a former Chairman of the English Law Commission, could not disguise his admiration for Lord Denning's approach. Perhaps it takes a professional law reformer of the 1980s to know the limitations of institutional law reform. Will a reference be given? How quickly can the report be made? Will it get through the bureaucracy? Will Parliament have the time to consider the report? Will Parliament change the recommendations?:

"I do feel very strongly that when you've got a supremely able person, as Lord Denning is, it is a good thing to have what you might call a pacemaker somebody who, if you like, goes a little bit too far and then others can put him right under our ordinary process of the courts and appeals and so forth. But it's a good idea to have somebody there who is a bit more visionary than the rest. And he is the ideal person." 53

If we have thrown away the fairy tale ${ }^{54}$ that judges do not make, but only discover the law, there is still a natural disinclination for judges to embrace too stridently the assertion of their law making functions. The passive and mechanical view of the judicial role is deeply embedded in the community's consciousness. ${ }^{55}$ The suspicion of too much candour or too much activism in judicial law-making arises from a fear of idiosyncratic personal judgments not grounded in a coherent framework of legal rules. This, for example, was Lord Hailsham's criticism of Lord Denning:

"I think there is a want of coherence in his approach to things. He has a very highly subjective view of the world, I think. Speaking simply now as one who has appeared before him, as well as read his judgments in the reports, one's never quite sure with Tom whether one's going to meet with the lion under the throne or the tribune of the people." 56

52. Lord Denning, interviewed by Hugo Young, supra n. 49, at p. 14.

53. M. Kerr, interviewed by Hugo Young, ibid, at p. 12.

54. Lord Reid, "The Judge As Lawmaker," (1972) 12 7.S.P.T.L. 22.

55. Lord Radcliffe, quoted in M. Cappelletti, "Who Watches the Watchman? A Comparative Study on Judicial Responsibility", (1983) 31 A.7.Com.L. 1.

56. Lord Hailsham, interviewed by Hugo Young, supra n. 49, at p. 10. 


\section{The Way of the Iconoclast}

Whether lawyers are scandalised by Denning or admire his persistence, courage and reforming zeal, he is clearly a great judge of our century who cannot be ignored. His judgments continue to have an influence on the life of the common law. We live in a time of change. People expect judges to help society meet the challenges of change. Leaving each and every reform to Parliament will simply not do. Denning reminds us of the original genius of the common law: adapting the law's reasonable predictability and certainty, to new times.

"What then is the way of an iconoclast?", he once asked an Oxford audience. "It is the way of one who is not content to accept cherished beliefs simply because they have been long accepted. If he finds that they are not suited to the times or that they work injustice, he will see whether there is not some competing principle which can be applied in the case in hand. He will search the old cases, and the writers old and new, until he finds it. Only in this way can the law be saved from stagnation and decay." 57

Reformer or Mischief-maker? Revolutionary judge or maverick? Lion under the throne or tribune? Iconoclast or harsh moralist? One thing is certain, Lord Denning has been a towering figure of the common law of our century. His passion for justice and reform carries lessons for all lawyers - and especially for those who take the judicial oath to do justice.

57. Lord Denning, “The Way of An Iconoclast", (1959) 5 7.S.P.T.L. 77, at p. 89. 